\title{
Academic Roots: The Past and Present of Entrepreneurial Marketing
}

\author{
Dr. Gerald E. Hills \\ Turner Chair and Professor of Entrepreneurship \\ Bradley University \\ 1501 West Bradley Avenue, Peoria, IL 61625 \\ E-mail: hills.gerald@gmail.com \\ Claes M. Hultman, $\mathrm{PhD}$ \\ Professor of Business Administration \\ Swedish Business School \\ Orebro University \\ SE-701 82 OREBRO, Sweden \\ Phone: +46-19303522 Fax: +46-19332546 \\ E-mail: claes.hultman@oru.se
}

Dr. Hills holds the Turner Endowed Chair in Entrepreneurship at Bradley University and he chairs the annual Research Symposium on Marketing and Entrepreneurship. His current research interests include entrepreneurial marketing and opportunity recognition.

Claes M. Hultman holds a chair in Marketing at Swedish Business School at Örebro University and he is the author of many books and articles in marketing \& entrepreneurship. His current research interests include entrepreneurial marketing and commercialisation processes in innovation based firms. 


\section{Abstract}

Research in Entrepreneurial marketing is about 30 years old. During this period research has followed many trajectories. Two important but divergent routes are small business marketing versus entrepreneurial marketing mirroring the discourse of small businesses versus entrepreneurial firms. Today small business marketing and entrepreneurial marketing are regarded as separate research fields, however related. EM-researches have been very openminded towards different approaches in methodology, especially compared to research within mainstream marketing in the US.

During this rather long period of time advances in other disciplines have been beneficial for our own research. One such example is the development of Effectuation theory allowing us to understand entrepreneurial decision-making and consequently, important aspects of entrepreneurial marketing behaviour.

Many of the research questions, regarded as important by scholars in a panel 1986, are still regarded as important, for example new venture growth. Other issues have lost its relevance. But over all many important questions still are waiting for an answer and the whole research field of Entrepreneurial marketing offers tremendous research opportunities. 


\section{Academic Roots: The Past and Present of Entrepreneurial Marketing}

\section{The growing importance of entrepreneurial marketing}

The importance of entrepreneurs and entrepreneurship are widely recognized. The entrepreneur has become a hero in recessionary times. And the ability to operate, and often also to grow, a business in a challenging business environment is important for society. So there is a need for scholarly studies of entrepreneurship and its intersections with other academic disciplines, such as marketing.

The basic idea of linking Marketing and Entrepreneurship has been discussed for many years. Early authors linking the two fields together were, for example, Murray (1981) and Tyebjee et al. (1983). In the 90s, both education at various university levels and published research in entrepreneurial marketing (EM) grew significantly. We find more courses, conferences and symposia organized than ever before (Hills et al. 2010).

Particularly satisfying is that the number of Ph.D. candidates and new dissertations in the field is increasing; some recent examples are Jones (2009) and FjelldalSoelberg (2010). This is very promising for future expansion and we expect an increasing number of young scholars disseminating new knowledge.

\section{Today It is a Scattered Research Field}

As in other emerging academic research fields, we can expect multi-direction development processes. Looking at EM in the past and its long journey, it is not surprising to 
find the present scholarly knowledge rather scattered. EM is not yet a well defined area of research and, in fact, we are continuing to define both the concept of EM and the research domain.

The lowest common denominator is the study object, the entrepreneur, and EM is directly linked to marketing as practiced by entrepreneurs as illustrated in Figure 1.

Figure 1

Entrepreneurial Marketing is the Result of Entrepreneurial Interpretation of Information, Decision-making and Marketing Actions

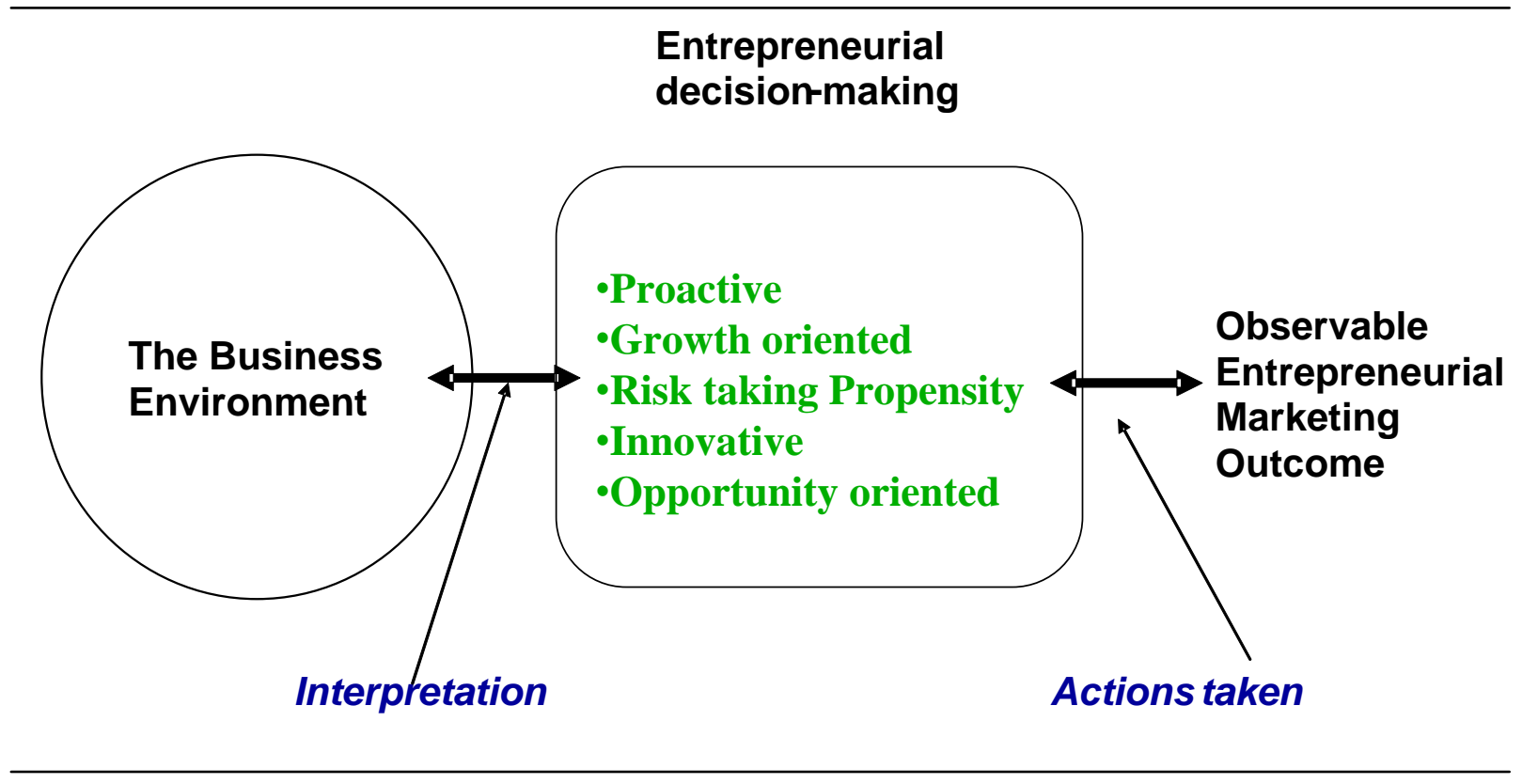

This is an important demarcation in contrast to mainstream marketing which can be regarded as marketing as practised by managers. The differences in business behaviours between entrepreneurs and managers are well documented in the literature; see for example Schultz and Hofer (1999) and Bjerke and Hultman (2002). It is reasonable to expect that marketing thinking and behaviour is different in accordance. And here we find a theoretical foundation and rationale for the development of EM. 
But not even the concept of an entrepreneur is clearly defined. Over the past 30 years entrepreneurs have been used both for the traditional small business owner and as for the high growth, high-tech entrepreneur. Within the evolution of EM this discrepancy has been reflected in a conceptual separation between small business marketing and entrepreneurial marketing as related, but dissimilar research fields, reflecting the differences in behaviour between a small business owner, running his or her business as a basic operation, in contrast to the behaviour of the innovative entrepreneur who continuously strives for growth.

The scattered state of the present EM research may be a weakness but it also opens tremendous opportunities for integrative research. In our opinion, EM is in a very exciting stage of development and we can expect a fruitful future with more conceptual and integrative research.

\section{The Definitions of EM}

Definitions of EM and its interface reflect entrepreneurial behaviour. Concepts such as change, innovations and opportunities are typically present. One example is an early definition of the interface (Gardner, 1994):

"...the interface of entrepreneurial behaviour and marketing is that where innovation is brought to market. ... Marketing's role in innovation, then, is to provide the concepts, tools, and infrastructure to close the gap between innovation and market positioning to achieve sustainable competitive advantages." 
As the interface has evolved, we have regarded EM to represent something more complex than just supply concepts and tools to position and create sustainable competitive advantage for new innovations. We have chosen to regard EM as a complex process as well as an orientation for how entrepreneurs behave at the marketplace, Hills et al. (2010):

"EM is a spirit, an orientation as well as a process of passionately pursuing opportunities and launching and growing ventures that create perceived customer value through relationships by employing innovativeness, creativity, selling, market immersion, networking and flexibility."

\section{EM's Relation to Mainstream Marketing - Converging or Diverging?}

Related to a paradigm discussion is the question of EM's relationship to one of its parents, the marketing discipline. U.S. mainstream marketing has dominated both education and research in the discipline for several decades. Therefore it is of special interest to analyse EM's relation to the definition of marketing provided by the American Marketing Association (AMA). For many years the AMA did not change their definition, but revisions were made in1935, 1982 and 2004 and the latest modification came in 2007.

As we can see in Table 1, the definition of marketing has evolved from being focused on performing business activities (1935) to focus on activities, institutions and processes for value creating offerings. At the time of the first marketing and entrepreneurship Symposium in 1982, mainstream marketing, as defined by the AMA in 1981, was very different from discussions of EM. But the way the AMA changed the definition in 2004 and 
in 2007, the gap has been reduced. Most entrepreneurs focus intensely on how to create, communicate and deliver value for customers, clients, partners and society at large.

Today we regard EM as research that supplements the established mainstream marketing theories, but focusing on marketing as performed by entrepreneurs. It's not a question of challenging the dominating perspectives of marketing. But it is a question of supplementing existing marketing theory with knowledge about marketing as performed by entrepreneurs. As entrepreneurs become increasingly important in the world economy we can expect EM to play a more prominent role in marketing theory. Such evolution may well lead to greater convergence between EM and mainstream marketing.

\section{EM is to Effectuate}

In the last decade, development of effectuation theory, Sarasvathy (2001), has offered important understanding of how EM differs from mainstream marketing. Effectuation processes, as implemented by entrepreneurs, may help to explain the uniqueness of EM as compared to traditional mainstream marketing. She contrasts effectuation processes to causation processes:

Causation processes take a particular effect as a given and focus on selecting between means to create the effect. Effectuation processes take a set of means as given and focus on selecting between possible effects that can be created with that set of means.

She cites Kotler's classic textbook, Marketing Management, as an example of causation processes, where the market is assumed to exist, classic market research methods are engaged, and marketing strategies and programs are developed with attention to 
segmentation, targeting and positioning. Sarasvathy contrasts this approach to the use of effectuation processes to start a new restaurant:

... (the entrepreneur) would have to proceed in the opposite direction...instead of starting with the assumption of an existing market and investing money and other resources to design the best possible restaurant for the given market, she would begin by examining the particular set of means or causes available to her.

With limited resources of only $\$ 20,000$ she thinks creatively about convincing an established restaurateur to become a strategic partner or using other approaches that allow the entrepreneur to create one of several possible effects irrespective of the generalized end goal with which she started. Effectuation processes allow a decision maker to change his or her goals and even to shape and construct them over time, making use of contingencies as they arise. The logic of effectuation processes is: to the extent that we can control the future, we do not need to predict it. The traditional logic of causation processes is: to the extent that we can predict the future, we can control it. The set of means encompasses who I am, what I know and whom I know. EM, including generating novel and useful ideas for business ventures, is a creative process.

Applying this theme to strategic management, it was concluded by Sarasvathy (2001) that the traditional view of attaining ends (for example profit, market share) must be complemented with entrepreneurship, the achievement of beginnings, the creation of products, firms and markets. The same observation may be made about the nature of EM. Although it is not possible to do justice to her theoretical contribution in so few words herein, we call on scholars to weigh her insights as we further develop EM. 


\section{Pluralistic View of Methodology}

It is interesting how pluralistic EM researchers have been regarding legitimate methodologies in research for the past 30 years. Especially within the academic North American mainstream, marketing as a positivistic, quantitative approach has been dominant. Yet within the field of EM, regardless of geographical and cultural origin, researchers seem to be open to accepting and applying different methodological approaches such as qualitative case studies, interpretive studies, grounded-theory research and others. This can be observed in proceedings from EM symposia. Some of the later examples of such proceedings are Würth and Gaul (2007); Hills et al. (2008); Kocak et al. (2009).

\section{Past and Current Research Opportunities}

The history of scholarly academic work regarding marketing and entrepreneurship was recently reviewed for the past quarter century by Hills, Hultman and Miles (2008). What has not been done, however, is to compare the perceived importance of specific M/E research issues by leading scholars at an early stage, in 1986, as compared to today. During that early period, there were three discussion oriented research workshops held with invited participating scholars. These meetings were held in conjunction with the annual conferences of the International Council for Small Business, the U. S. Association for Small Business and Entrepreneurship and the American Marketing Association. These closely preceded the first Research Symposium on Marketing and Entrepreneurship. As noted in the first Conference proceedings (that came to be called the "blue books"), the 
objective was to engage in brainstorming and discussion to identify critical knowledge voids and to attach research priorities. As presented at that time:

If a theory is a systematically related set of statements, including some law like generalizations, that are empirically testable, then the starting point is to work toward that so called set of statements (Hunt 1976, 3). This was the objective of the Symposium - to initiate this process. We inevitably adopted what Zaltman called the "theories in use" approach, an inductive process that in this case assumed that the current practices of successful entrepreneurs provided an appropriate source for identifying researchable propositions (Zaltman, LeMasters and Heffings 1982, 113-138.). Still today we need concepts at the M/E interface, the building blocks of theory, and also taxonomies if we are to progress. There was also a call for longitudinal studies, to better understand the process of new venture creation and growth.

So 21 invited panelists in the workshops first offered their high priority research issues, and then there was an exchange of ideas for a total of 10 hours in the three meetings. Additional participants were added who were well known to be knowledgeable in this research realm. Based on tape recordings and notes, the research questions shown in Table 2 were listed and rated on a 10-point importance scale from 1 (most important) to 10 (least important).

In 2010, for comparative purposes, the leading scholars currently were identified by peers, a questionnaire using the research questions from nearly a quarter century ago was developed and the leading researchers were emailed the questionnaire to obtain their ratings, again on a 10 point scale. This survey of expert opinion resulted in 20 respondents. 
Using " 5 " as the midpoint on a 10-point scale as our measure of "importance", we can then draw implications. In the case of the $t 1$ (1986) means, all of the research questions were viewed as "important". Currently (t2), however, 20 of the original 28 research questions were considered to be important $(\leq 5.00)$. There were nine questions reported in the historical study for which there were no $t 1$ means in Table 2 , however, and 5 of these were "important" currently $(t 2 \leq 5.00)$. Including these research questions results in 25 of the $t 2$ research question means being "important", certainly confirming that numerous research opportunities remain at the marketing/entrepreneurship interface as perceived by leaders in the field. This, of course, does not include many other opportunities not identified long ago at t1.

Why are half of the research questions in time period 1 no longer viewed as important? Hopefully, this is partly explained by the new knowledge that has been generated in the past two decades, thereby offsetting the void that existed! Respondents in this survey were also asked to indicate research questions where there has been "significant" progress in addressing these questions. Several respondents did not reply to that request, but some indicated that progress had indeed been made regarding a number of research topics. So, indeed, several questions may be less important today because of progress due to research. It may also be that some expert respondents are more confident in their replies due to learning that has taken place over time. This could be contributing to higher standard deviations today and more "unimportant" means.

Let us now examine the 10 most important research questions shown in Table 2. Looking to the lower means (and highest importance) currently, the question regarding 
new venture growth is revealing. What curtails growth in new ventures, lack of owner/ entrepreneur propensity or such market limitations as size and the window of opportunity? This factor may be the most important influence affecting firm growth. Also, the inadequacy of market research techniques for identifying market opportunities is increasingly noted. Opportunity recognition is a market and marketing focused process and yet the mainstream marketing discipline has largely ignored the need for new knowledge in this area. Instead, the focus is only on evaluation after the initial identification of the business idea.

The research question in Table 2 regarding a "departure from a planned marketing strategy" is also striking, given our knowledge today of the vast number of business plans that are modified or aborted early on in response to market forces.

Another highly rated research opportunity concerns niche marketing. Despite the temptation to assume this is most appropriate, there are clearly numerous exceptions. Why? Is this an evolutionary issue that must be considered at various stages of growth, for example? This leads us to a similar but broader question regarding the entire marketing function within the organization. To what extent does marketing change over time and with respect to firm growth?

Also concerning market research, the research question that addresses the stage of organizational growth as it pertains to being "out of touch" with its markets is revealing. At what stage does the entrepreneur begin to need formal market research to replace the loss of day-to-day market immersion? 
The seventh ranked question again concerns the issue of flexibility of marketing strategies under uncertainty. There is also a specific focus on not only failures in general, but market-related failures (vs. for example, technology). Of considerable importance as well is the relationship between the creativity process and the marketing process. A related manuscript recently presented a creativity model of the opportunity recognition process and there is a significant conceptual parallel. And tied for the top 10 in current importance, the leadership role of the entrepreneur is equal in importance to the promotion function when no image or market presence exists.

It may be seen in Table 2 that the remaining "important" research questions $(\leq$ 5.00) refer to several uniquenesses of new firms that seemingly demand differences in marketing. For example, there is attention to no customer loyalty, a need for more qualitative research into market feasibility, less marketing professional infrastructure, solo leadership start-ups, technology and other types of product markets, intuitive decision making by entrepreneurs, early life cycle uniquenesses as well as smaller firm size, pricing flexibility and the unique pressure to generate cash flow. Marketing educators are also challenged to determine if their curricula are non-entrepreneurial!

The "unimportant" $(\geq 5.00)$ items currently are shown in Table 2 because in studying the response distributions, nearly all questions resulted in skewed distributions supporting the importance of the items as seen by at least some of our expert respondents. Also, with certain questions, it appears that the expert respondents no longer debate existing support, so there is less importance attributed as a research question. 
Finally, as shown in Table 3 , the changes in mean importance between $t 1$ and $t 2$ are rank ordered, with all but one of the changes representing a shift to being less important as compared to more than two decades ago. Beginning with the largest change with a mean of 2.01 (on the 10-point scale) is attention to contingency/situation based marketing strategy, feasibility methodologies and avoiding formal market research. Several other research questions dropped in importance as well, confirming the discussion just concluded. If there is less than a .5 difference in the means of $t 1$ and $t 2$, they are not listed in Table 3 . Using this decision guideline, the one item of higher importance concerned the conditions dictating "a departure from planned marketing strategy".

To conclude, despite the differences, it should be noted that if we were to define "important" to be 6.0 on a 10-point scale, rather than 5.0, only one questionnaire item in Table 2 would be unimportant. This bodes well for the array of important research opportunities going forward. And going beyond this historical analysis, there are numerous new, current research opportunities with a significant theoretical base that are not addressed here.

\section{Epilogue}

Looking at the rich research that has evolved for the last 30 years, and with the world-wide recognition of the importance of entrepreneurs, EM research can be expected to grow substantially in importance. As can be expected, research questions vary over time and some seem to be valid for a long period. The theoretical foundations for EM need to be better clarified and we need more empirical observations to reveal the complexity of EM behaviour. 
But each conference and each special issue of established international journals dedicated to

EM are important supplements to the already existing outlets for our joint research efforts.

SPECIAL THANKS---The following experts contributed their research importance ratings to this study: Nicole Coviello, Jenny Darroch, Jonathan Deacon, Fabian Eggers, Joseph

Giglierano, Kenneth Grant, David Hansen, Gerald Hills, Claes Hultman, Chicery Kasouf, Sascha Kraus, Morgan Miles, Michael Morris, Sussie Morrish, Gina O'Connor, Minet Schindehutte, Robert Schwartz, Stanley Stasch, Richard Teach, and Can Uslay,

\section{References}

Bjerke, B. \& Hultman, C. Entrepreneurial Marketing - The Growth of Small Firms in the New Economic Era, Cheltenham, UK: Edward Elgar Publishing Ltd, 2002, ISBN 1-84064-912-7.

Fjelldal-Soelberg, F. (2010) Entreprenöriell marknadsföring: Ett Studie av Entreprenörskap og Marknadsföring som Overlappande Fenomenområder. Dissertation at Bodö Graduate School of Business, Bodö, Norway, ISBN 978-82-92893-13-5.

Gardner, D. (1994) in Hills, G. (ed) Marketing and Entrepreneurship: Research Ideas and Opportunities, Westport, CN, Quorum Books.

Hills, G.E. and Hultman, C.M. (2006) Entrepreneurial Marketing, In Lagrosen, S. and Svensson, G., editors, Marketing - Broadening the Horizons. Lund: Studentlitteratur.

Hills, G., Hultman, C., Kraus, S. \& R. Schulte (2010) "History, Theory and Evidence of Entrepreneurial Marketing - An Overview" in International Journal of Entrepreneurship and Innovation Management (IJEIM), Vol. 11, No. 1, 3-18.

Hills, Gerald \& Hultman, Claes \& Morgan Miles (2008) "The Evolution and Development of Entrepreneurial Marketing” in Journal of Small Business Management, 46 (1), 99-112 
Hills, Gerald, Hultman, C., Monllor, J. \& Laurel Ofstein (eds.) (2008) Research at the Marketing/Entrepreneurship Interface, Chicago, UIC.

Hunt, Shelby D. (1976), Marketing Theory: Conceptual Foundations of Research in Marketing, Columbus, OH: Grid, Inc..

Jones R. (2009) Entrepreneurial Marketing in small Welsh technology firms: an empirical study. Dissertation at Bangor Business School, Bangor University, UK.

Kocak, A., Abimbola, T., Özer, A. and Watkins-Mathys, L. (2009) Marketing and Entrepreneurship, Proceedings from AUMEC 2009, Ankara, Turkey.

Murray, J. (1981) "Marketing is Home for the Entrepreneurial Process" in Industrial Marketing Management, Vol. 10, 93-99.

Sarasvathy, S. (2001) 'Causation and Effectuation. Toward a Theoretical Shift from Economic Inevitability to Entrepreneurial Contingency' in Academy of Management Review, Vol. 26, No 2, 243-263.

Schultz III, William and Charles W. Hofer (1999), Creating Value through Skill-based and Entrepreneurial Leadership, Kidlington, Oxford, UK: Pergamon.

Tyebjee, T, Bruno, Albert and Shelby McIntyre (1983) 'Growing ventures can anticipate marketing stages’ Harvard Business Review, Jan-Feb., 62-66.

Würth, Reihold and Wolfgang Gaul, W. (ed) (2007) "Marketing/Entrepreneurship Interface: Revisited and Future Directions" in: The Entrepreneurship-InnovationMarketing Interface: $2^{\text {nd }}$ Symposium. Künzelsau, Germany, Swiridoff Verlag.

Zaltman, Gerald, Karen LeMasters and Michael Heffring (1982), Theory Construction in Marketing: Some Thoughts on Thinking, New York: John Wiley and Sons, 113138. 
Table 1

American Marketing Association's Definitions of Marketing

\section{5}

"...the performance of business activities that direct the flow of goods and services from producers to consumers"

\section{1}

Marketing is the process of planning and executing the conception of ideas, goods and services to create exchanges that satisfy individual and organizational objectives"

2004

Marketing is an organizational function and a set of processes for creating, communicating and delivering value to customers and for managing customer relationships in ways that benefit the organization and its stakeholders

2007

Marketing is the activity, set of institutions, and processes for creating, communicating, delivering, and exchanging offerings that have value for customers, clients, partners, and society at large.

Table 2

Past (t1) and Present (t2) Research Opportunity Importance in the Field of Entrepreneurial Marketing: Most Important (1) to Least Important (10) in $t 2$

\begin{tabular}{llll}
\hline $\begin{array}{l}\text { Research Question } \\
\text { To what extent is firm growth a function of }\end{array}$ & $\begin{array}{c}\text { Rank } \\
\text { Order (t2 } \\
\text { Means) }\end{array}$ & $\begin{array}{c}\text { Standard } \\
\text { Deviation } \\
\text { (t2) }\end{array}$ & $\begin{array}{c}\text { Comparable } \\
\text { t1 Means }\end{array}$ \\
\hline $\begin{array}{l}\text { market limitations (such as size and window } \\
\text { of opportunity) as opposed to owner } \\
\text { propensity for growth? }\end{array}$ & 3.55 & 2.34 & 4.00 \\
$\begin{array}{l}\text { How can market research techniques be better } \\
\text { developed and used to }\end{array}$ & & & \\
$\begin{array}{l}\text { identify market opportunities? } \\
\begin{array}{l}\text { What conditions dictate a departure from a } \\
\text { planned marketing strategy? }\end{array}\end{array}$ & 3.64 & 2.75 & 3.15 \\
$\begin{array}{l}\text { Is niche marketing more linked to } \\
\text { entrepreneurial success than the pursuit of } \\
\text { larger, broader markets? }\end{array}$ & 3.73 & 2.66 & 4.65 \\
\hline
\end{tabular}


How does the marketing function within the organization develop over

time and with firm growth?

When does a firm grow to a size at which it is

"out of touch" with its markets

and needs formal market research?

Should marketing strategies be more flexible under high conditions of uncertainty?

Are there more market-related venture failures than technology/product

based failures?

Is there a parallel between the creativity process and the marketing process?

Is the interpersonal, leadership role of the owner/entrepreneur critical to implementing marketing strategy?

How is the promotion function different for a new enterprise with no image

How is the appropriate marketing strategy different when no customer loyalty exists at start up?

Should marketing studies for new firms be more qualitative vs. quantitative as compared to mature firms?

Can marketing curricula content in universities be characterized as nonentrepreneurial?

Is a non-price based strategy better for new/small firms than for larger, mature firms (with more resources)?

Is there less professional marketing infrastructure for entrepreneurs

Can new, unique products be priced so as to enhance the perceived value?

Do new businesses face greater uncertainty and less data availability than mature firms?

Is there an inverse relationship in ventures between technology sophistication and marketing sophistication?

What differences exist between early life cycle businesses and small firms?

Is marketing decision making more often a solo process in new firms vs.

Do entrepreneurs make intuitively vs. scientifically based marketing 
planning process?

To reach cash break even, do firms use a

combination of marketing strategies

to shorten the process?

Are certain types of product/markets better for

starting new ventures?

Do business to business relationships often

lead to cooperation on new

product/service development?

Can a roll out strategy and market test reduce new venture risks?

What methodologies can best enable us to screen new business vs. new product market feasibility?

Do entrepreneurs avoid marketing research due to their blind faith in their idea/product?

Is access limited to high quality sales people in new independent ventures?

Is a made-to-order or custom vs. a commodity strategy better for small/new firms?

Are competitive market position and margins more important to new firm success

than the management team?

Do entrepreneurs typically underbudget for and underestimate the requirements for marketing their products?

Are innovative new products faced with great uncertainty, due in part to the absence of market information?

Do most venture business plans substantially overstate the amount and the timing of demand?

What role does luck play in market opportunity identification and market strategy success?

Do new ventures have difficulty in obtaining good quality distribution arrangements?

Is marketing strategy success in new ventures typically contingency (or 
Table 3

Historical Changes in Research Question Importance (means $\mathbf{t 2}$ minus t1) Largest to Least Change in Mean Importance

\begin{tabular}{lc}
\hline & $\begin{array}{c}\text { Difference } \\
\text { (t2 minus } \\
\text { t1) }\end{array}$ \\
Research Question & 2.01 \\
\hline $\begin{array}{l}\text { Is marketing strategy success in new ventures typically contingency (or } \\
\text { situation) based? }\end{array}$ & 1.83 \\
$\begin{array}{l}\text { What methodologies can best enable us to screen new business vs. new } \\
\text { product market feasibility? }\end{array}$ & 1.51 \\
$\begin{array}{l}\text { Do entrepreneurs avoid marketing research due to their blind faith in their } \\
\text { idea/product? }\end{array}$ & 1.31 \\
$\begin{array}{l}\text { Do entrepreneurs make intuitively vs. scientifically based marketing } \\
\text { decisions (and rely less on a corporate-type planning process? }\end{array}$ & \\
$\begin{array}{l}\text { Are innovative new products faced with great uncertainty, due in part to the } \\
\text { absence of market information? }\end{array}$ & 1.15 \\
$\begin{array}{l}\text { Is a non-price based strategy better for new/small firms than for larger, mature } \\
\text { firms (with more resources)? }\end{array}$ & 1.11 \\
$\begin{array}{l}\text { Are competitive market position and margins more important to new firm } \\
\text { success } \\
\text { than the management team? }\end{array}$ & \\
$\begin{array}{l}\text { What role does luck play in market opportunity identification and market } \\
\text { strategy success? }\end{array}$ & 1.10 \\
$\begin{array}{l}\text { Is a made-to-order or custom vs. a commodity strategy better for small/new } \\
\text { firms? }\end{array}$ & 1.02 \\
$\begin{array}{l}\text { Are there more market-related venture failures than technology/ product } \\
\text { based failures? }\end{array}$ & 0.82 \\
$\begin{array}{l}\text { To reach cash break even, do firms use a combination of marketing strategies } \\
\text { to shorten the process? }\end{array}$ & 0.82 \\
$\begin{array}{l}\text { Is there an inverse relationship in ventures between technology sophistication } \\
\text { and marketing sophistication? }\end{array}$ & 0.68 \\
$\begin{array}{l}\text { Is there less professional marketing infrastructure for entrepreneurs } \\
\text { (vs. accounting, legal) and if so, why? } \\
\text { What conditions dictate a departure from a planned marketing strategy? }\end{array}$ & 0.63 \\
\hline
\end{tabular}

